\title{
Phytoplankton Inventory and Diversity in Floating-Net-Cages Area of Lake Maninjau, West Sumatra
}

\author{
${ }^{1}$ Jabang Nurdin ${ }^{*},{ }^{2}$ Desra Irawan, ${ }^{3}$ Hafrijal Syandri, ${ }^{4}$ Nofrita, ${ }^{5}$ Rizaldi, ${ }^{6}$ Adityo Raynaldo \\ ${ }^{1,2,4,5,6}$ Department of Biology, Faculty of Mathematics and Natural Sciences, Andalas University, West \\ Sumatra, Indonesia \\ ${ }^{3}$ Faculty of Fisheries, Bung Hatta University, West Sumatra, Indonesia
}

\begin{abstract}
A study on inventory and diversity of phytoplankton in the floating-net-cages area of Lake Maninjau has been carried out from five different sites (Muko-muko, Koto Kaciak, Kubu Baru, Tanjung Sani, Sigiran). Sampling was conducted in the surface water and incubation zone (Secchi depth) from each site, start from November 2017 to January 2018. This study aims to identify phytoplankton species and diversity, also habitat quality due to floating-net-cages activities in Lake Maninjau. A standard method was followed in this study to identify phytoplankton species and calculated the biological index. Other factors recorded including the characteristic of aquatic habitat, temperature, TDS, TSS, and $\mathrm{pH}$. From the observation, we found 17 species of phytoplankton consist of 4 Classes. Phytoplankton diversity index $\left(\mathrm{H}^{\prime}\right)$ ranged from 2.42 to 2.62 with the highest diversity index found in Muko-Muko and Sigiran (2.42 and 2.62) while the lowest in Koto Kaciak and Tanjung Sani (1.63 and 2.18). Phytoplankton Evenness index (E) ranged from 0.41 to 0.67 with the highest value found in surface water and incubation zone in MukoMuko and Sigiran (0.64 and 0.67, respectively) while the lowest found in Koto Kaciak (0.41 and 0.60, respectively). Phytoplankton dominance index (D) ranged from 0.87 to 0.92 with the highest dominance index found in surface water and incubation zone in Sigiran, Muko-Muko, Koto Kaciak, and Kubu Baru (0.90) and Sigiran (0.92) while the lowest found in Tanjung Sani (0.89 and 0.87). From this study, we can conclude that feed residue from floating-net-cage activity causes impairment in water quality and can be detected from the physical-chemical factors of Lake Maninjau.
\end{abstract}

Keywords: Diversity, floating-net-cages, Lake Maninjau, phytoplankton

\section{Introduction}

Lake Maninjau is one of five lakes in West Sumatra, including Lake Singkarak, Lake Diateh, Lake Dibawah, and Lake Talang. Lake Maninjau is one of the largest lakes formed by tecto-volcanic activity, located in Agam Regency, West Sumatra. Geographic location $0^{0} 15{ }^{\prime} 10^{\prime \prime}-0^{0} 24{ }^{\prime} 11^{\prime} \mathrm{S}$ and $100^{0} 8{ }^{\prime} 45^{\prime}-$ $100^{\circ} 13$ ' $37^{\prime \prime}$ E with an altitude of 450 masl. Lake surface area approximately 9,950 ha, the maximum length is $12 \mathrm{~km}$, width $6.5 \mathrm{~km}$ and depth is approximately $167 \mathrm{~m}$ (Center of Environmental Studies Andalas University, 1984 and Merina, 2014).

Lake Maninjau has been used for drinking water sources, hydroelectric power, transportation, tourism areas, fishing areas and intensive fish farming using floating-net-cages for many years. Around the lake, there are various human activities such as agriculture, cultivation, and settlement. Lake Maninjau is currently in a heavily polluted state, one of the causes is fish farming activities using floating-net-cages (Syandri et al., 2014 and Syandri, 2016). Floating-net-cages activities can cause high sediment load in the lake's water body. The amount of sediment in Lake Maninjau from 2001 to 2013 reaching 111,889.84 tons with an average of 9,324.98 tons/year (Junaidi et al., 2014), on another report Syandri et al (2014) stated from 2001 to 2015 the amount of sediment in Lake Maninjau reaching 178,889 tons.

Inorganic nitrogen and phosphate accumulation in waters causing trophic conditions and eutrophication. In Lake Maninjau, these elements come from fish feed residues and fish dead (Syandri et al., 2014 \& 2017), also discharges of organic pollutants from anthropogenic activities to the waters that could be disrupting the 
balance of existing organisms. In this situation, the overgrowing of phytoplankton often occur and could be harmful to other aquatic biotic communities (Abuka, 2012).

Trophic conditions or eutrophication under certain conditions could stimulate the growth of surface aquatic plants which will be covering the waters and causing ecological conditions impairment. Eutrophication is a natural condition that is commonly occurring in lentic water, but the expansion of activity of fish farming in water bodies causing uncontrolled eutrophication (Sitorus, 2009). Eutrophication can be determined from the trophic level of a water body and distribution of the phytoplankton in water.

Recent publications of phytoplankton in Lake Maninjau is quietly limited. In 1984, the Center of Environmental Studies of Andalas University reported 20 species of phytoplankton in Lake Maninjau. Mayunar (1985) reported 92 species of phytoplankton, in another report, Afrizal (1988) found 23 species of phytoplankton, Astriyeni (2001) found 65 species of phytoplankton and Merina (2014) found 94 species of phytoplankton. By the date, since the changes in the Physico-chemical condition over fish-farming and other anthropogenic activities in Lake Maninjau, recent information about the phytoplankton community in Lake Maninjau are needed. Therefore, this study aims to collect recent information about species presence and diversity of phytoplankton and habitat quality in the floating-net-cages area of Lake Maninjau.

\section{Methodology}

\section{Study area and sample collection}

This study was conducted in September 2017 - March 2018 using survey methods. Sampling location is determined by "purposive sampling" refer to Sitorus (2009), namely the site of Muko-Muko (Site 1), Koto Kaciak (Site 2), Kubu Baru (Site 3), Tanjung Sani (Site 4) and Sigiran (Site 5) (Figure 1). Phytoplankton was collected in surface water and incubation zone (Secchi depth). Analysis of water samples is carried out at the Laboratory of Biology, Andalas University.

\section{Sampling procedure}

For surface waters, water sampling is carried out using a 15-liter bucket with three replications and for incubation zone, water sampling is done using a Lamotte Water Tube sample volume of 2,250 ml with twenty replications, during optimal sunlight at $09.00 \mathrm{am}-02.00 \mathrm{pm}$. Analysis of water samples, both phytoplankton and physicochemical parameters were carried out at the Laboratory of Ecology, Department of Biology, Andalas University. Phytoplankton samples were observed with a Zeiss Primo Star iLED Microscope with a 40x100 magnification refer to the book: Freshwater Biology (Edmondson, 1966), Illustration of the Plankton of Japan (Mizuno, 1974), Prescoot (1979), Yamaji (1980), Planktonologi (Sachlan, 1982), Bold \& Wynne (1985) and Pascher (1986).

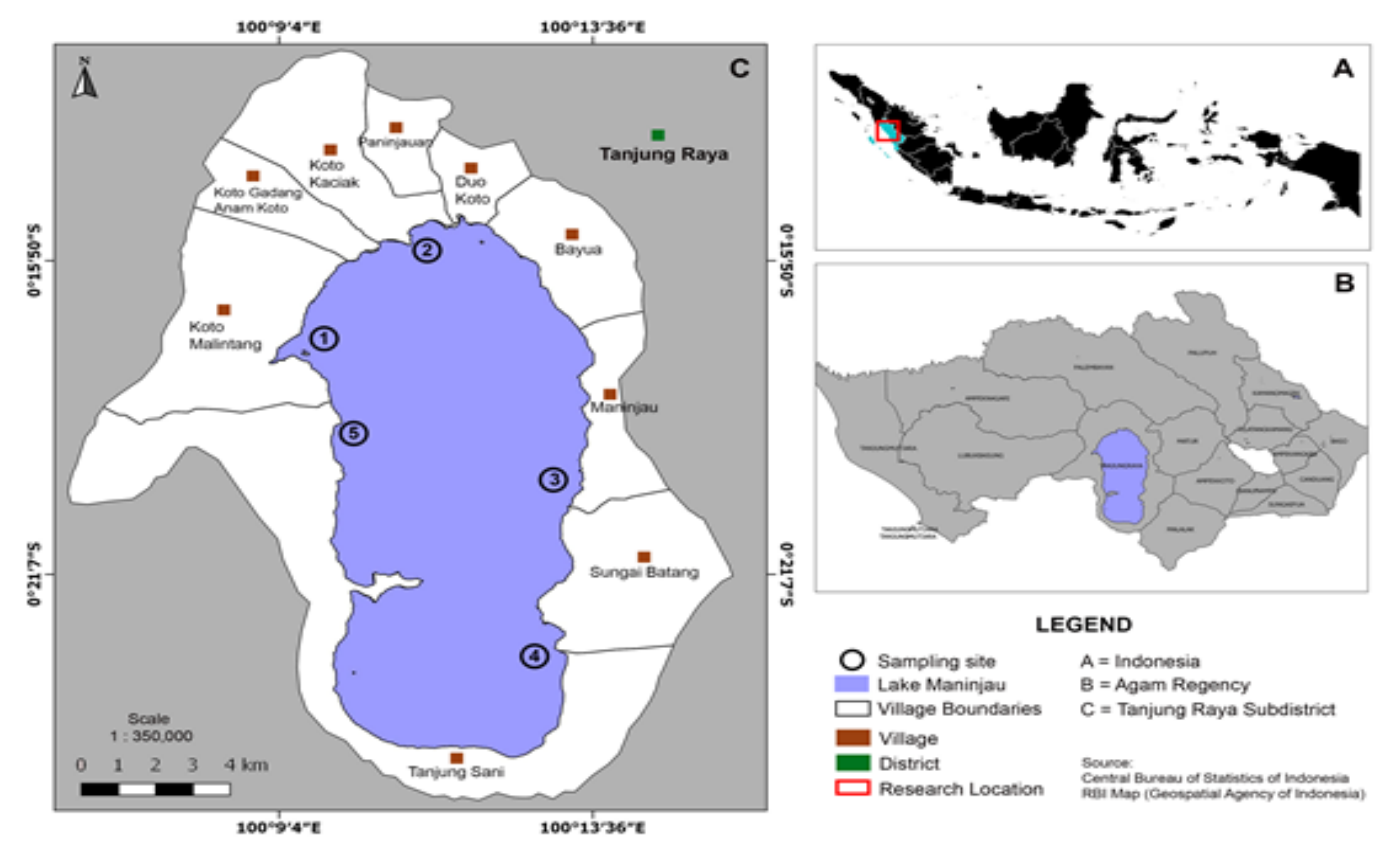

Figure 1: Map of research location and sampling sites in Lake Maninjau 


\section{Data analysis}

Shannon-Wiener diversity index (Poole, 1974), (Michael, 1984), Sitorus (2009):

$$
H^{\prime}=-\sum\left[\frac{n_{1}}{N}\right] \operatorname{Ln}\left[\frac{n_{1}}{N}\right]
$$

Where.

$H^{\prime}$ : Diversity index.

ni : Number of cells of i-species

$\mathrm{N}$ : Total number of cells.

The Shannon-Wiener diversity index range can be categorized as follows:

$\mathrm{H}^{\prime}<1=$ Low diversity and low stability of community condition

$1<\mathrm{H}^{\prime}<3=$ Medium diversity and medium stability of community condition

$\mathrm{H}^{\prime}>3=$ High diversity and high stability of community condition

Evenness index (equitability) refer to the Michael (1984) equation:

$$
E=\frac{H^{\prime}}{H^{\prime} M a x}
$$

Where.

E : Evenness index

H'max : Ln S

S : Number of species

The dominance index (Simpson) ranges from 0-1 and can be calculated using the following formula (Odum, 1971):

$$
D=\sum\left[\frac{n_{1}}{N}\right]
$$

Where.

D : Dominance index

ni : Number of cells of i-species

$\mathrm{N}$ : Total number of individual.

\section{Results and Discussion}

\section{Phytoplankton Inventory}

From this study, we recorded 17 species of phytoplankton in 4 classes, i.e Bacillariophyceae (9 species), Chlorophyceae (5 species), Cyanophyceae (2 species) and Euglenophyceae (1 species). Phytoplankton species found were Cymbella tumida, Gomphonema elongatum, Melosira granulate, Synedra ulna, Pinnularia viridis, Nitszchia sigma, Navicula cuspidate, Ephitemia sp. and Fragillaria sp. (Bacillariophyceae). Oedogonium mitratum, Cosmarium compressus, Closterium sp., Pediastrum duplex, and Spyrogyra micropunctata (Chlorophyceae). Oscillatoria sp., Rivularia haematites (Cyanophyceae), and Phacus sp. (Euglenophyceae). Most species in the Bacillariophyceae class were present at all sites except Fragillaria sp. (not found in Site V). Cyanophyceae, Chlorophyceae, and Euglenophyceae are quite diverse (Figure 2). Widely distribution species of phytoplankton that found in all sites in Bacillariophyceae class (Cymbella tumida, Gomphonema elongatum, Melosira granulate, Synedra ulna, Pinnularia viridis, Nitszchia sigma, Navicula cuspidata, Ephitemia sp.), Chlorophyceae class (Pediastrum duplex, Spyrogyra micropunctata), and Cyanophyceae class (Oscillatoria sp. and Rivularia haematites).

A study from Samudra (2013) in Lake Rawa Pening which currently in eutrophic status found 37 types of phytoplankton consisting of 5 classes, Bacillariophyceae (12 species), Chlorophyceae (16 species), Cyanophyceae (7 species), Euglenophyceae (1 species) and Pyrrophytaea (1 species). Ruttner (1977) also 
found common phytoplankton species in freshwater from Bacillariophyceae, Chlorophyceae, Cyanophyceae, Eugleanophyceae, Dinophyceae, and Chrysophyceae classes.

\section{Phytoplankton Diversity \\ Diversity Index (H), Evenness (E), Dominance (D) in Lake Maninjau}

Phytoplankton diversity index values in the surface waters and incubation zones found in Muko-muko (2.36 and 2.62), Koto Kaciak (2.42 and 2.43), Kubu Baru (2.28 and 2.18), Tanjung Sani (1.63 and 2.39) and Sigiran (2.09 and 2.36, respectively) (Figure 3). The highest phytoplankton diversity index values in surface water and incubation zone were found in Koto Kaciak and Muko-muko sites (2.42 and 2.62, respectively) while the lowest found in Tanjung Sani and Kubu Baru sites (1.63 and 2.18, respectively). Phytoplankton diversity index in the surface waters ranged from 1.63-2.42 and in incubation zones ranged from 2.18-2.62, with no significant value $(\mathrm{P}<0.001)$. The highest diversity means in surface water and incubation zones were 2.42 and 2.62 .

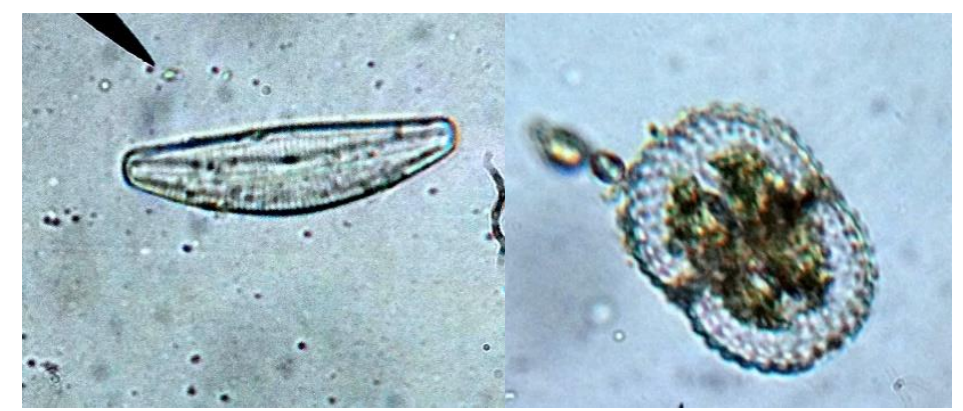

Cymbella tumida

Cosmarium magnificum

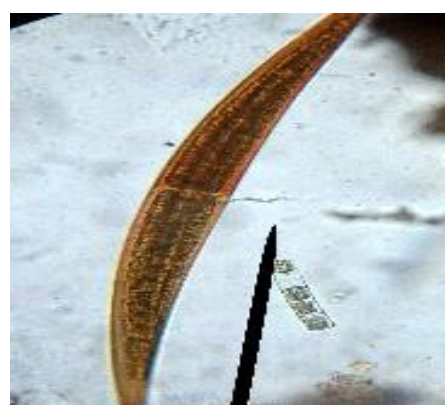

Closterium sp.

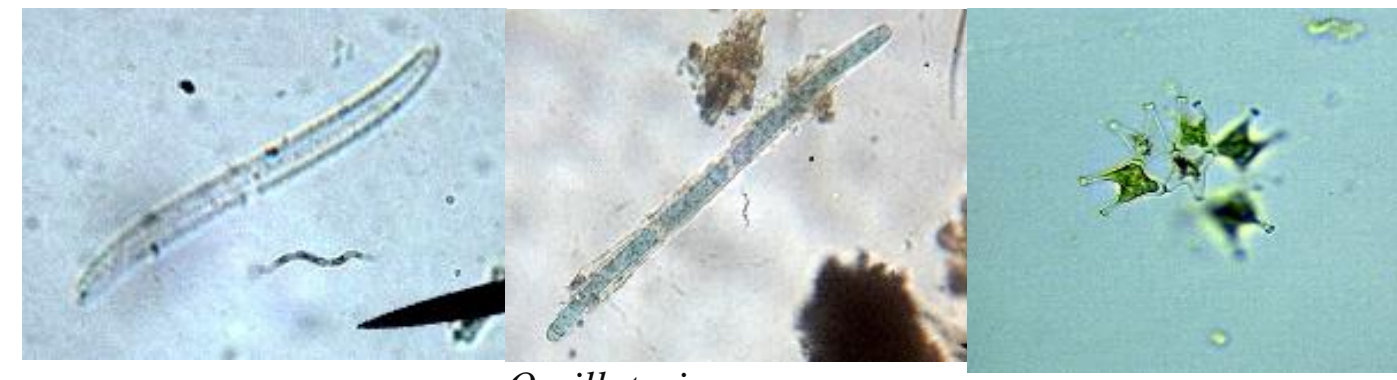

Nitzschia sigma

Oscillatoria sp.

Pediastrum duplex

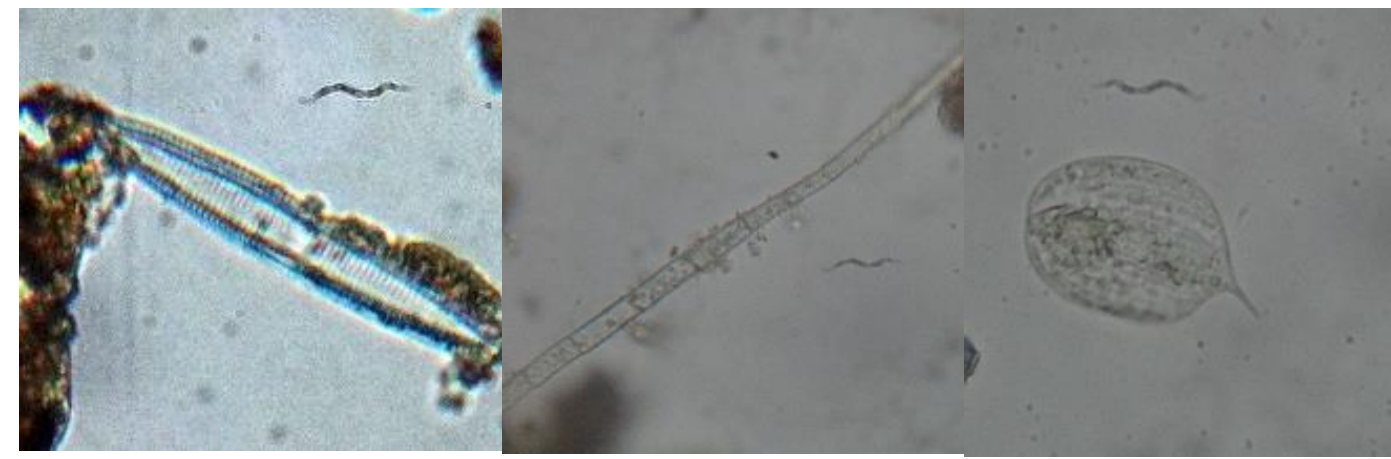

Synedra ulna

Oedogonium sp.

Phacus sp. 


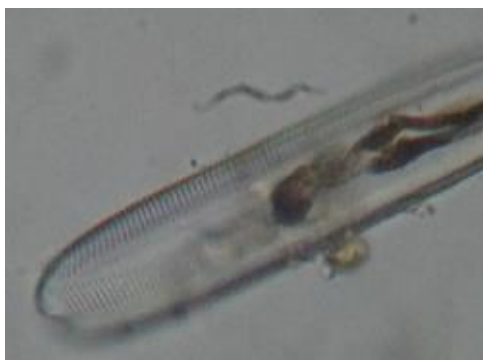

Pinularia viridis

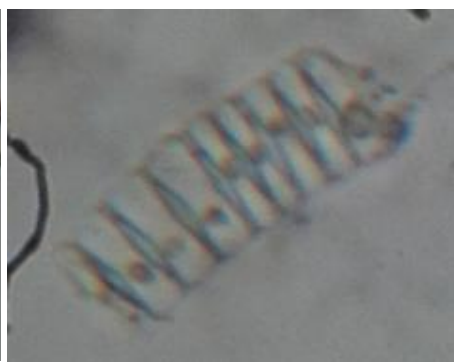

Fragillaria sp.

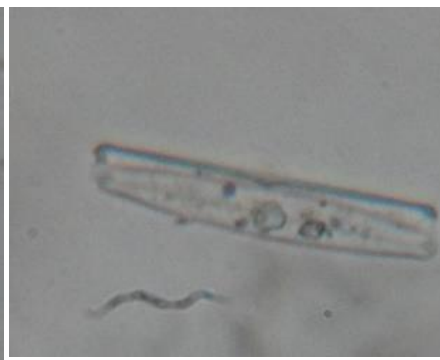

Navicula cuspidate

\section{Figure 2: Several dominant species of phytoplankton in Lake Maninjau with a magnification of $40 \times 100$}

From this study, we found that Nitszchia sigma from the Bacillariophyceae class is a main species of phytoplankton communities of surface water and incubation zone in Lake Maninjau. According to Sachlan (1982), genus Nitszchia is a single-celled diatom that can live in polluted waters with high levels of organic content. Species of Nitszchia and Synendra is also a group of diatoms that are found in freshwaters (Tjitrosoepomo, 2001). Bacillariophyceae is a phytoplankton group that has a high growth and development rate, high tolerance, able to adapt to environmental changes and efficiently utilizes small amounts of nutrients(Hatta, 2009). Thus, Bacillariophyceae has widely distributed in the waters of Lake Maninjau. Moreover, Bacillariophyceae have cell walls composed of silica, fast-reproduction, able to adapt to environmental conditions and grow well on low aquatic nutrients (Odum, 1993; Arinardi et al., 1994; Langus, 2004; Arifin, 2009).

Evenness index of phytoplankton of surface water and incubation zone in Muko-muko (0.59 and 0.67, respectively), Koto Kaciak (0.64 and 0.65), Kubu Baru (0.63 and 0.62), Tanjung Sani (0.41 and 0.60) and Sigiran (0.51 and 0.61) (Figure 3). The highest phytoplankton evenness index values in surface water and incubation zone were found at the Koto Kaciak and Muko-Muko locations ( 0.64 and 0.67, respectively) while the lowest found in Tanjung Sani (0.41 and 0.60, respectively). The evenness index in surface water ranged from 0.41 to 0.64 , in incubation zone ranged from 0.60 to 0.67 . The highest evenness means in surface water and incubation zone were 0.64 and 0.67 .

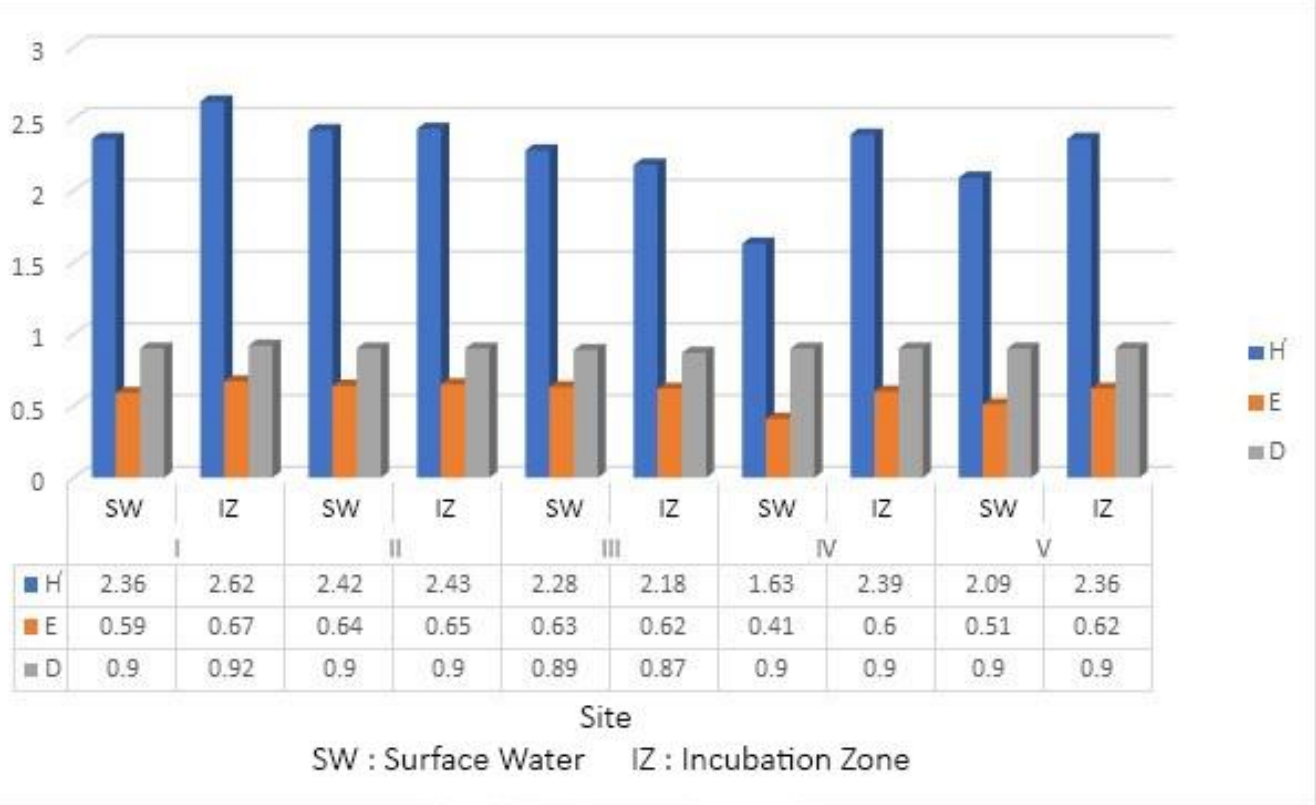

Figure 3 Diversity Index (H'), Evenness (E), Dominance (D) of surface waters and incubation zones in Lake Maninjau

Dominance index of phytoplankton in surface water and incubation zone found in Muko-muko ( 0.90 and 0.92, respectively), Koto Kaciak (0.90 and 0.90), Kubu Baru (0.89 and 0.87), Tanjung Sani and Sigiran (0.90 and 0.90) (Figure 3). The highest value of dominance index in surface water and incubation zone 
found in Muko-Muko, Koto Kaciak, Tanjung Sani and Sigiran (0.90), while the lowest found in surface water and incubation zone of Kubu Baru site (0.89 and 0.87). Phytoplankton dominances index in surface water and incubation zone ranged from 0.89 to 0.90 and 0.87 to 0.92 .

Based on the Shannon-Wiener diversity index, phytoplankton communities in Lake Maninjau currently in medium levels, medium stability of communities, number of species and individuals is also moderate and regularly distributed. Current phytoplankton's diversity of Lake Maninjau in this study is lower than the previous study from Sasmita (2001), Kencanawati (2001) and Marina (2014). Decreasing diversity levels may be influenced by the ecological threshold of Lake Maninjau ecosystems, environmental factors for phytoplankton growth and physicochemical factors among the sampling site. Odum (1993) diversity levels of community are mainly determined by species richness and distribution of individuals.

Phytoplankton communities in Lake Maninjau shows that the number of individuals among species is relatively similar and there are no dominant species. These results indicate that there is no significant difference in the evenness index in surface water and incubation zone in Lake Maninjau ( $\mathrm{P}<0.001)$. In general, evenness values in surface water and incubation zone are relatively high with index value is close to 1. The evenness index is ranged from 0 to 1 , greater values indicate a high degree of evenness. Suin (2002) classifies phytoplankton type based on environmental factors, can be divided into five groups by the frequency of occurrence.

Phytoplankton composition in Lake Maninjau shows that the number of individuals among species is relatively similar and there are no dominant species. These results indicate that there is no significant difference in the dominance index in surface water and incubation zone in Lake Maninjau $(\mathrm{P}<0.001)$. In general, dominance values in surface water and incubation zone are relatively high with index value is close to 1

\section{Habitat characteristics and quality of Lake Maninjau}

Observation in habitat quality conducted in all sites in Lake Maninjau; Muko-Muko, Koto Kaciak, Kubu Baru, Tanjung Sani, and Sigiran. Muko-muko site located in coordinates S: $00^{\circ} 17^{\prime} 15^{\prime \prime}$ and E: $100^{\circ} 09^{\prime} 08^{\prime \prime}$, from observation we found floating-net-cages activities, water hyacinth (Eichornia crassipes) domination, settlement, tourism areas, conservation areas, sandy mud substrate, littoral waters. Koto Kaciak with coordinates S: $0^{\circ} 15^{\prime} 32^{\prime \prime}$ and E: $100^{\circ} 11^{\prime} 09^{\prime \prime}$, we found floating-net-cages activities, settlement, rice fields, water hyacinth and Hydrilla present, mud substrate, sloping littoral waters. Kubu Baru with coordinates S: $0^{\circ} 18^{\prime} 09^{\prime \prime}$ and E: $100^{\circ} 13^{\prime} 13$ ', floating-net-cages activities also found, settlement, hospitals, sandy substrate, littoral waters. Tanjung Sani with coordinates S: $0^{\circ} 21^{\prime} 20^{\prime \prime}$ and E: $100^{\circ} 12^{\prime} 54^{\prime \prime}$, we found floating-net-cages activities, sandy-rocky substrate, present of benthic aquatic plants, littoral waters. Sigiran site with coordinates S: $0^{\circ} 20^{\prime} 03^{\prime \prime}$ and E: $100^{\circ} 09^{\prime} 54^{\prime \prime}$, we also found floating-net-cages activities, settlement area, mud substrate.

Table 1: Water Quality Parameters in Lake Maninjau.

\begin{tabular}{|l|l|l|l|l|l|}
\hline \multirow{2}{*}{ Site } & Depth & Temperature $\left({ }^{\mathbf{0}} \mathbf{C}\right)$ & TDS $(\mathbf{m g} / \mathbf{L})$ & TSS $(\mathbf{m g} / \mathbf{L})$ & $\mathbf{p H}$ \\
\hline \multirow{2}{*}{1} & Surface Water & 28 & 23,45 & 10,30 & 6 \\
\cline { 2 - 6 } & Incubation zone & 28 & 31,09 & 15,48 & 7 \\
\hline \multirow{2}{*}{2} & Surface Water & 29 & 33,55 & 18,06 & 7 \\
\cline { 2 - 6 } & Incubation zone & 29 & 35,78 & 18,44 & 7 \\
\hline \multirow{2}{*}{3} & Surface Water & 29 & 18,16 & 13,35 & 6 \\
\cline { 2 - 6 } & Incubation zone & 29 & 23,71 & 16,04 & 7 \\
\hline \multirow{2}{*}{4} & Surface Water & 29 & 11,06 & 5,41 & 6 \\
\cline { 2 - 6 } & Incubation zone & 29 & 12,95 & 8,20 & 6 \\
\hline \multirow{2}{*}{5} & Surface Water & 29 & 47,28 & 18,49 & 7 \\
\cline { 2 - 6 } & Incubation zone & 29 & 47,28 & 18,49 & 6 \\
\hline
\end{tabular}


Water quality in Lake Maninjau is described from physical-chemical characteristics, temperatures in surface water and incubation zones ranged from $28-29^{\circ} \mathrm{C}$ and $28-29^{\circ} \mathrm{C}$, respectively. Total Dissolved Solids (TDS) of surface waters and incubation zones in all sites were found to range from 11.06 to $47.28 \mathrm{mg} / \mathrm{L}$ and 12.95 to $35.78 \mathrm{mg} / \mathrm{L}$, respectively. The highest TDS value of phytoplankton in surface waters and incubation zones was found in Sigiran (47.28 mg/L), while the lowest in Tanjung Sani (12.95 mg/L) (Table 1).

From the observation, Total Suspended Solid (TSS) of surface water and incubation zones ranged from 5.41 to $18.49 \mathrm{mg} / \mathrm{L}$ and $8.20-18.49 \mathrm{mg} / \mathrm{L}$, respectively. The highest TSS value of phytoplankton in surface waters and incubation zone found in Sigiran $(18.49 \mathrm{mg} / \mathrm{L})$, while the lowest was found in Tanjung Sani $(8.20$ $\mathrm{mg} / \mathrm{L})$. Observation of $\mathrm{pH}$ value in surface water and incubation zones found in all sites ranged from 6-7.

Parsons et al. (1984) stated that the basic important characteristics of light are quantity and quality. Effendi (2003) explains the fluctuations of water turbidity mainly affect TDS value. Fluctuations of water temperature depending on time, space and weather conditions. Fardiaz (1992) states that suspended solids can cause water turbidity and are not settling immediately. Ameliawati (2003) recorded TSS concentrations $<25 \mathrm{mg} / \mathrm{L}$ in Cimandiri River Estuary did not impair the fisheries activities. According to Marganof (2007) in general, the fluctuation of TSS concentration in Lake Maninjau is still in the good category with $\mathrm{pH}$ values ranging from 7.32-7.38.

\section{Conclusion}

1. From this study in Lake Maninjau, we found 17 species phytoplankton were representing 4 classes; Bacillariophyceae, Chlorophyceae, Cyanophyceae, and Euglenophyceae. The number of species of each class is respectively Bacillariophyceae 9 species, Chlorophyceae 5 species, Cyanophyceae 2 species, and Euglenophyceae 1 species.

2. The highest diversity index of phytoplankton in surface water and incubation zone were found in Koto Kaciak and Muko-Muko sites (2.42 and 2.62) while the lowest found in Tanjung Sani and Kubu Baru (1.63 and 2.18). The highest evenness levels found in Koto Kaciak and Muko-Muko (0.64 and 0.67) while the lowest at Tanjung Sani (0.41 and 0.60). The highest dominance index found in Muko-Muko, Koto Kaciak, Tanjung Sani and Sigiran (0.90 each), while the lowest found in Kubu Baru (0.89 and $0.87)$.

3. Feeding residues due to floating-net-cage activity may causing impairment of water quality in Lake Maninjau and can be observed from the physicochemical factor in Lake Maninjau.

\section{Acknowledgment}

The authors are very grateful to the Head of Ecology Laboratory of Biology Department, Andalas University. Thank you the local community leaders and chief of Selingka Nagari Lake Maninjau for providing facilities and support.

\section{References}

[1.] Ameliawati. (2003). Water Quality Characteristics at Cimandiri River Mouth, Pelabuhan Ratu, Sukabumi, West Java. [Undergraduate Thesis]. Department of Water Resource Management. Faculty of Fisheries and Marine Science. IPB. Bogor. [In Indonesian].

[2.] Arifin, R. (2009). Spatial and Temporal Distribution of Phytoplankton Biomass (Chlorophyll-a) and its Relation to the Fertility of Estuary Waters of the Brantas River, East Java. IPB. Bogor. [In Indonesian]

[3.] Abuka, M. (2012). Eutrophication in shallow lakes and water dams. In. A Magazine for the environmental centre for Arab Towns. Issue 2 December 2012. Eu.envirocitiesmag.com/article/pdf/article.pdf.

[4.] Afrizal, S. (1988). Vertical Distribution of Ephylitic Diatoms in Muko-Muko on Lake Maninjau. [Undergraduate Thesis]. FMIPA Andalas University. Padang. [In Indonesian]

[5.] Arinardi, O.H., Trimaningsih dan Sudirjo. (1994). Introduction to Plankton and the Range of Abundance and Predominant Plankton Around Java and Bali. Puslitbang Oseanologi-LIPI. Jakarta. [In Indonesian]

[6.] Astriyeni, E. (2001). Phytoplankton Composition and Primary Productivity Within and Outside the Floating-Net-Cages in the Village of Muko-muko Lake Maninjau. [Undergradiate Thesis]. FMIPA Andalas University. Padang. [In Indonesian] 
[7.] Astuti, N. (2003). Composition and Structure of the Plankton Community and Bada Fish Population in the Bada Catching Area at Lake Maninjau. [Undergraduate Thesis]. FMIPA Andalas University. Padang. [In Indonesian]

[8.] Bold, H. C. and M. J. Wynne. (1985). Introduction to the Algae. Second Editon. Prentice Hall Inc. Engelwood Cliffs. New York.

[9.] Edmondson, W. T. (1966). Fresh-Water Biology. United States of America: University of Washington.

[10.] Effendi, H. (2003). Water Quality Study for Resource and Environmental Management. Kanisius. Yogyakarta. 98 p. [In Indonesian]

[11.] Mizuno, W. T. (1959). Frehwater Biology. Second Edition. John Willey and Sons. London.

[12.] Fardiaz S. (1992). Water and Air Pollution. Kanisius. Yogyakarta [In Indonesian]

[13.] Hatta, M. (2009). Relationship Between Phytoplankton Primary Productivity and Nutrients at Secchi Depth in the Hydroelectric Water of Koto Panjang Reservoir, Riau. IPB. Bogor [In Indonesian]

[14.] Junaidi., Syandri,H. and Azrita. (2014). Loading and distribution of organic materials in Maninjau Lake West Sumatra Province-Indonesia.Journal Aquactic Research Development

[15.] Kencanawati, I. (2001). Composition and Structure of Phytoplankton Communities in the Lake Kerinci Lithoral Zone. [Undergraduate Thesis]. FMIPA Andalas University. Padang. [In Indonesian]

[16.] Langus, A. (2004). Spesies - Spesific Differences in Phytoplankton Responses to N and P Enrichment and the N-P Ration in the Archipelago Sea. Northern Baltic Sea.

[17.] Marganof. (2007). Water Pollution Control Model in Lake Maninjau West Sumatra. IPB. Bogor. [In Indonesian]

[18.] Merina, G. (2014). The composition and structure of the phytoplankton community in Lake Maninjau. [Undergraduate Thesis]. FMIPA Andalas University. [In Indonesian]

[19.] Mayunar. (1985). Phytoplankton Composition in the Lithoral Zone at Lake Maninjau. [Undergraduate Thesis]. FMIPA Andalas University. Padang. [In Indonesian]

[20.] Michael, P. (1984). Ecological Methods for Field and Laboratory Investigations. Translator: Yanti R, Koestoer. UI Press. Jakarta.[In Indonesian]

[21.] Mizuno, T. (1974). Illustrations of the Freshwater Plankton of Japan. Hoikusha Pusblishing. New Delhi.

[22.] Odum E. P. (1971). Fundamentals of Ecology. Third Edition. Philadelphia, London, Toronto: W. B. Sounders Company.

[23.] Odum, E. P. (1993). Fundamentals of Ecology. Translator: T. Samingan. Gadjah Mada University Press. Yogyakarta. 697 p. [In Indonesian]

[24.] Parsons, T. R, M. Takahashi, dan B. Hargrave. (1984). Biological Oceanographyc Processes. Pergamon Press. 3rd Edition. New York-Toronto. Volume 277, Number 1/March, 1994 Pages1-15.

[25.] Pascher, B. V.A. (1986). Bacillariophyceae. Vet Gustav Fischer Verlag. Juin.

[26.] Center of Environmental Studies Andalas University (PSLH). (1984). Aquatic and Aquatic Biotic Research of Lake Singkarak, Lake Maninjau, Lake Diateh, Lake Dibawah. West Sumatra Province. Andalas University. Padang. [In Indonesian]

[27.] Poole, R. W. (1974). An Introdruction to Quantitative Ecology. GrGraw-Hill. Kogosuco. Tokyo.

[28.] Prescott, G. W. (1978). Fresh Water Algae.Third Edition.Wm.C.Brown Company Publisher. London.

[29.] Ruttner. (1977). Fundamental of Limnology. University of Toronto Press. Canada

[30.] Sachlan, M. (1978). Planktonology. Lembaga Oceanologi Indonesia. Jakarta. [In Indonesian]

[31.] Sachlan, M. (1982). Planktonology. Faculty of Animal Husbandry and Fisheries, Diponegoro University. Semarang. 177 p. [In Indonesian]

[32.] Samudra, R.M, T.R, Retnaningsi \& M, Izzati. (2013). Composition, Abundance and Diversity of Phytoplankton in Lake Rawa Pening, Semarang Regency. BIOMA, Vol 15, No. 1, p. 6-13 [In Indonesian]

[33.] Sasmita, (2001). Composition and structure of the phytoplankton community in the littoral zone of Lake Maninjau. [Undergraduate Thesis]. FMIPA Andalas University. [In Indonesian] 
[34.] Sitorus. M. (2009). Relationship Between Primary Productivity Value with Chlorophyll-a Concentration, and Physical-Chemical Factors in Lake Toba, Balige, North Sumatra. [Master Thesis]. Sumatera Utara University. Medan. [In Indonesian]

[35.] Suin, N. M. (2002). Ecological method. CV. Tannabur Andal Guna Padang. [In Indonesian]

[36.] Syandri H., Junaidi.,Azrita. and Yunus T. (2014). State of aquatic resources Maninjau Lake West Sumatra Province, Indonesia.Journal of Ecology and Environmental Sciences, 1 (5) : 109-113.

[37.] Syandri, H. (2016). Water Quality Conditions in the Floating-Net-Cage Fish Maintenance Area at Lake Maninjau. J Prosiding Seminar Nasional Tahunan Ke-V Hasil-Hasil Penelitian Perikanan dan Kelautan. P. 301-310. [In Indonesian].

[38.] Syandri, H., Azrita., and Ainul. (2017). Levels of Available Nitrogen-Phosphorus Before and After Fish Mass Mortality in Maninjau Lake of Indonesia, Indonesia. Journal of Fisheries and Aquaculture, 12 (4): 191-196.

[39.] Tjitrosoepomo, G. (2001). Plant Taxonomy. Yogyakarta: Gajah Mada University Press. [In Indonesian]

[40.] Yamaji, I. 1980. Illustration of the marine plankton of Japan. Hoikusha Publishing Co. ltd. Japan. 